\title{
Correction of Renal Tubular Acidosis in Carbonic Anhydrase II-deficient Mice with Gene Therapy
}

\author{
Li-Wen Lai, ${ }^{\star}$ Deva M. Chan, ${ }^{\star}$ Robert P. Erickson, ${ }^{\ddagger}$ S. Jeff Hsu, ${ }^{\ddagger}$ and Yeong-Hau H. Lien* \\ *Department of Medicine and ${ }^{\ddagger}$ Department of Pediatrics, University of Arizona Health Sciences Center, Tucson, Arizona 85724
}

\begin{abstract}
Carbonic anhydrase II (CAII) deficiency in humans is associated with a syndrome of renal tubular acidosis, osteopetrosis, and cerebral calcification. A strain of mice of CAII deficiency due to a point mutation also manifests renal tubular acidosis. We report here that retrograde injection of cationic liposome complexed with a CAII chimeric gene, using a cytomegalovirus (CMV) promoter/enhancer as an expression cassette to drive human CAII cDNA, into the renal pelvis of CAII-deficient mice results in expression of CAII in the kidney. The levels of both the CAII gene and its corresponding mRNA were highest by day 3 after treatment, diminishing thereafter, but remaining detectable by 1 mo. After gene therapy, CAII-deficient mice restored the ability to acidify urine after oral administration of ammonium chloride. The ability to acidify urine was maintained at $3 \mathrm{wk}$ after gene therapy, and was eventually lost by $6 \mathrm{wk}$. Immunohistochemistry studies using anti-CAII antibodies showed that CAII was expressed in tubular cells of the outer medulla and corticomedullary junction. The gene therapy was not associated with nephrotoxicity as assessed by blood urea nitrogen levels and renal histology. To our knowledge, this is the first successful gene therapy of a genetic renal disease. Our results demonstrate the potential of gene therapy as a novel treatment for hereditary renal tubular defects. ( $J$. Clin. Invest. 1998. 101:1320-1325.) Key words: liposome • gene transfer • kidney $\bullet$ renal tubules $\bullet$ inborn errors of metabolism • immunohistochemistry
\end{abstract}

\section{Introduction}

Carbonic anhydrase II (CAII) ${ }^{1}$ is an isozyme of the CA family that catalyzes the reversible hydration of carbon dioxide (1). CAII is a cytoplasmic enzyme located in the proximal tubule, loop of Henle, and intercalated cells in the collecting duct of the kidney (2). Outside the kidney, CAII is found in a variety

Address correspondence to Yeong-Hau H. Lien, M.D., Ph.D., Section of Nephrology, Department of Medicine, University of Arizona Health Science Center, 1501 N. Campbell Ave., Tucson, AZ 85724. Phone: 520-626-6370; FAX: 520-626-2024; E-mail: lien@u.arizona.edu Received for publication 10 September 1997 and accepted in revised form 28 January 1998.

1. Abbreviations used in this paper: BUN, blood urea nitrogen; CAII, carbonic anhydrase II; CMV, cytomegalovirus; RT, reverse transcription; TBS, Tris-buffered saline.

J. Clin. Invest.

(C) The American Society for Clinical Investigation, Inc. 0021-9738/98/04/1320/06 \$2.00

Volume 101, Number 7, April 1998, 1320-1325

http://www.jci.org of cells including osteoclasts and glia cells (3). Carbonic anhydrase II deficiency in humans is an autosomal recessive disease characterized by renal tubular acidosis, osteopetrosis, cerebral calcification, and growth retardation (4). Lewis et al. (5) produced a strain of CAII null mice by an induced mutation that resulted in mice with growth retardation and renal tubular acidosis. A point mutation was found at $\mathrm{Gln}^{154}$ that leads to premature termination of translation (1). It has been established that in CAII-deficient mice urine $\mathrm{pH}$ and chloride excretion is higher and titratable acid output is lower than in control mice (6). These mice are unable to acidify urine after challenge with an acid load $(5,6)$. Since the CAII gene is well characterized (7) and the role of CAII on urine acidification has been well studied, the CAII-deficient mouse serves as an ideal animal model for developing gene therapy targeting to the renal tubules.

Previously, we demonstrated that cationic liposomes are effective for gene transfer in the kidney (8-10). Cationic liposomes, composed of a cationic lipid and a neutral lipid, have been used as vehicles for gene transfer both in vitro and in vivo. Since the initial report of lipofection in cultured cells by Felgner et al. in 1987 (11), the efficacy and safety of the in vivo use of liposomes have been demonstrated in studies of experimental animals $(12,13)$ and human gene therapy clinical trials $(14,15)$. Cationic liposomes are useful for gene delivery in the liver (16), lung (17), and cancers (13). When a mixture of Lipofectin (GIBCO BRL, Gaithersburg, MD), a cationic liposome preparation, and the cytomegalovirus (CMV)/ $\beta$-galactosidase expression plasmid was injected into the renal artery or retrogradely infused via the renal pelvis, $\beta$-galactosidase was expressed only in renal tubular cells, but not in glomerular, vascular, or interstitial compartments of the kidney (8-10). In this study, we further evaluated the efficacy and safety of intrarenal-pelvic liposomal delivery of the CAII gene on correction of renal tubular acidosis in the CAII-deficient mice model.

\section{Methods}

Animals. CAII-deficient mice were bred and maintained at the University of Arizona animal care facility in accordance with the National Institute of Health guidelines. The original pair of heterozygous breeders, C57BL/6J CAR-2, were purchased from The Jackson Laboratories (Bar Harbor, ME). The resulting F1 male mutants were crossed to normal female $\mathrm{C} 3 \mathrm{H}$ strain mice and the heterozygous $\mathrm{F} 2$ females were backcrossed to the F1 male mutants. The resulting homozygous-deficient mice have a similar phenotype in terms of growth curves and urine $\mathrm{pH}$ values (both baseline and after acid load) compared with the original C57BL/6J CAR-2 mutant. Female CAII-deficient mice weighing 16-20 $\mathrm{g}$ were used for liposome/DNA injection.

Construction of the chimeric CAII genes. The plasmid pCMVCAII was constructed by inserting the EcoRI-XbaI fragment of human CAII cDNA (kindly provided by Drs. P.J. Venta and R.E. Tashian Michigan State University, East Lansing, MI and University of Michigan, Ann Arbor, MI, respectively) into a pCI-neo vector (Promega Corp., Madison, WI) containing CMV promoter/enhancer region as an expression cassette, an upstream T7 RNA polymerase promoter 
site for in vitro transcription, and a simian virus 40 late polyadenylation signal for polyadenylation of transcribed mRNAs. An in vitrocoupled transcription/translation assay was performed using a coupled reticulocyte lysate system (Promega Corp.) that provides all the components required for transcription and translation of a coding sequence initiated on an upstream RNA polymerase promoter site. The pCMVCAII produced a $29-\mathrm{kD}$ protein equivalent to the molecular mass of human CAII (data not shown). Plasmid purification was performed using Qiagen endotoxin-free column (QIAGEN Inc., Chatsworth, CA) according to the manufacturer's instruction.

Intrarenal-pelvic infusion. Injection of the gene was performed as described previously (8). After anesthesia with phenobarbital (0.06 $\mathrm{mg} / \mathrm{g}$ body weight, i.p.), a midabdomen incision was made. Kidneys were exposed and the ureter and ureteropelvic junction freed of connective tissues and vascular structures. The ureter was clamped and pCMVCAII DNA/Lipofectin mixture $(20 \mu \mathrm{g}$ DNA and $50 \mu \mathrm{l} \mathrm{Lipo-}$ fectin in $200 \mu \mathrm{l}$ of $5 \%$ dextrose) was injected into the kidney using a 30 -gauge needle through the ureteropelvic junction. The ureter clamp was removed 5 min later, the incision was closed, and the mouse allowed to recover. For mock injections, a control plasmid, pCMV $\beta$ gal, containing $\beta$-galactosidase cDNA, was injected in the same way as the experimental group.

RNA/DNA isolation. Mouse kidneys were harvested and immediately homogenized in TRI REAGENT (Molecular Research Center, Cincinnati, $\mathrm{OH}$ ) for RNA isolation performed according to the manufacturer's instruction. DNA isolation was performed using the QIAamp Tissue Kit (QIAGEN Inc.) according to the manufacturer's instruction.

$P C R$. Isolated genomic DNA was subjected to PCR analysis using a set of primers specific for the human CAII cDNA, $\left(5^{\prime}\right.$ primer: 5'-TTTCACTGGGGTTCACTTGATG-3' [exon 3] and 3' primer: 5'-AAACACCCGAAGATTCATTATTTG-3' [exon 7]) that yields a 512-bp PCR fragment. PCR amplification was performed in a reaction volume of $25 \mu \mathrm{l}$ containing $300 \mathrm{ng}$ of genomic DNA, $10 \mathrm{mM}$ Tris$\mathrm{HCl}, \mathrm{pH}$ 9.0, $50 \mathrm{mM} \mathrm{KCl}, 1.5 \mathrm{mM} \mathrm{MgCl}, 0.1 \%$ Triton X-100, $200 \mu \mathrm{M}$ dNTPs, $2.0 \mu \mathrm{Ci}$ of $\alpha-\left[{ }^{32} \mathrm{P}\right] \mathrm{dCTP} ; 20 \mathrm{pmol}$ of primers, $1 \mathrm{U}$ of Taq DNA polymerase, and $220 \mathrm{ng}$ of TaqStart antibody (CLONTECH Laboratories, Inc., Palo Alto, CA). Amplification was performed using a PowerBlock cycler (Epicomp, San Diego, CA) with 35 cycles of denaturation at $94^{\circ} \mathrm{C}$ for $30 \mathrm{~s}$, annealing at $60^{\circ} \mathrm{C}$ for $30 \mathrm{~s}$, extension at $72^{\circ} \mathrm{C}$ for $40 \mathrm{~s}$, and a final cycle at $72^{\circ} \mathrm{C}$ for $5 \mathrm{~min}$. In parallel, standards were amplified from purified plasmid in the amount of $0,5,19,75$, and 300 $\mathrm{fg}$, with $300 \mathrm{ng}$ of negative genomic DNA representing $0,0.008,0.031$, $0.125,0.5$ copies of plasmids per genome, respectively. The amplified PCR fragments were resolved by $1 \times$ GeneAmp Detection Gel (Perkin-Elmer Corp., Norwalk, CT) electrophoresis. The gel was dried and an autoradiogram developed after a 2-16-h exposure time. PCR products were quantitated by comparing intensities of the 512-bp band of the samples, measured by $\beta$-scope (Betagen, Waltham, MA), to plasmid standards run in parallel.

Reverse transcription-PCR. Total RNA samples were treated with RNase-free RQ1 DNase (1 U per $\mu \mathrm{g}$ of RNA; Promega Corp.) and extracted with phenol-chloroform to eliminate possible residual DNA. Reverse transcription (RT) was performed in a reaction volume of $20 \mu \mathrm{l}$ containing $2 \mu \mathrm{g}$ of DNase-treated RNA, 60 pmol of 3' primer, $50 \mathrm{mM}$ Tris- $\mathrm{HCl}, \mathrm{pH} 8.3,75 \mathrm{mM} \mathrm{KCl}, 3.0 \mathrm{mM} \mathrm{MgCl}_{2}, 10 \mathrm{mM}$ DTT, $500 \mu \mathrm{M}$ dNTPs, and $200 \mathrm{U}$ Superscript II (GIBCO BRL) at $42^{\circ} \mathrm{C}$ for $1 \mathrm{~h}$. The cDNA generated by RT reaction $(1 \mu \mathrm{l})$ was amplified using the same PCR conditions as described above. Each DNasetreated RNA sample without conversion to cDNA was also used as a PCR template in parallel, to make sure that amplification of potentially contaminating plasmid DNA did not occur. RT-PCR products of the samples and standards were quantitated by using a $\beta$-scope to measure the intensity of product bands.

Acid loading test. Urine $\mathrm{pH}$ was measured by using $\mathrm{pH}$ reagent strips (Whatman Inc., Maidstone, UK) on voided droplets. Baseline urine $\mathrm{pH}$ values were recorded while the mice were on regular drinking water. The acid load was performed by replacing drinking water with a $0.6 \% \mathrm{NH}_{4} \mathrm{Cl}$ and $2 \%$ sugar solution for $2 \mathrm{~d}$. The weight of the liquid and body weight of the mice were monitored daily to make sure that animals were not dehydrated.

Immunohistochemistry studies. Immunohistochemistry studies using antibodies against human CAII were performed on renal sections from normal mice and CAII-deficient mice with or without gene therapy. Mice were anesthetized with pentobarbital and perfused through the left ventricle of the heart first with $60 \mathrm{ml}$ of PBS and then with 60 $\mathrm{ml}$ of $4 \%$ paraformaldehyde-PBS. The kidney was removed and fixed in $4 \%$ paraformaldehyde-PBS for $4 \mathrm{~h}$ at room temperature. After the tissue was embedded in paraffin, $6-\mu \mathrm{m}$ sections were deparaffinized with xylene and alcohol, rehydrated, blocked with Tris-buffered saline (TBS; $150 \mathrm{mM} \mathrm{NaCl}, 50 \mathrm{mM}$ Tris, $\mathrm{pH} \mathrm{7.4)}$ ) and $2 \%$ fetal bovine serum for $10 \mathrm{~min}$. Primary antibodies, sheep anti-human CA II antibodies (The Binding Site Inc., San Diego, CA) were diluted $(1: 1,000)$ using TBS, $1 \%$ BSA, $0.1 \%$ sodium azide, and $0.1 \%$ Tween 20 and incubated with kidney sections overnight at $4^{\circ} \mathrm{C}$. After washing with TBS and $0.1 \%$ Tween 20 and blocking with TBS and $2 \%$ fetal bovine serum, secondary antibodies conjugated with alkaline phosphatase were applied for $1 \mathrm{~h}$ at room temperature. The color reaction was carried out in nitro blue tetrazolium chloride/5-bromo4-chloro-3-indolyl-phosphate solution (Boehringer Mannheim Corp., Indianapolis, IN) according to the manufacturer's instruction, with 10 min pretreatment in $2 \mathrm{mM}$ levamisole. The counterstain was performed using Nuclear Fast Red.

Part of the kidney tissues were fixed with $10 \%$ buffered formaldehyde and the sections were stained with hematoxylin-eosin for detection of possible tissue injuries due to gene therapy.

Blood urea nitrogen. Blood samples were collected in mice with or without gene therapy, at the time of death and blood urea nitrogen levels were measured using the urease method (18).

\section{Results}

Detection of human CAII DNA by PCR. The human CAII cDNA was detected in CAII-deficient kidneys after gene therapy by PCR on day 3, 7, 14, 21, and 32 after injection (Fig. $1 a$, lanes 6-10). Semiquantitative studies were performed using a set of standards that represent $0,0.008,0.031,0.125,0.5$ copies of plasmids per genome, respectively (lanes $1-5$ ). There were more than 0.5 plasmid copies per genome detected in the injected kidney harvested on day 3 and 7 after therapy (lanes 6 and 7). The plasmid levels decreased to $0.5-0.125$ plasmid copies per genome on day 14 (lane 8 ), and 0.03-0.008 plasmid copies per genome on day 21 and 32 (lanes 9 and 10).

Detection of human CAII $m R N A$ in injected kidney by RT$P C R$. Fig. $1 b$ shows the RT-PCR results from representative animals that received gene therapy. To estimate the percentage of cells transfected and expressing the CAII transgene in each injected kidney, a set of standards were run in parallel with sample RNA. The standards were prepared by mixing total RNA from human renal adenocarcinoma cell lines, ACHN (obtained from American Type Culture Collection, Rockville, MD) with total RNA from CAII-deficient mouse kidney in a ratio of $0,1: 1,280,1: 320,1: 80$, and 1:20 (lanes $1-5$ ). On day 3 post-injection (lane 6), the human CAII gene expression in the injected kidney was higher than the standard containing ACHN RNA at 1:20 (lane 5). On day 7 (lane 8) the CAII mRNA level decreased to $40 \%$ of that on day 3 . Subsequently, the CAII RNA decreased to 12,5 , and $2 \%$, respectively, on day 14, 21, and 32 (lanes 10, 12, and 14). Since the abundance of CAII mRNA produced in an individual cell varies, our method only estimates the relative expression of the CAII transgene in each injected kidney. Each RNA sample was also 
used as a PCR template in parallel, without conversion to cDNA (lanes 7, 9, 11, 13, and 15). No significant levels of PCR products were detected from the RT $(-)$ samples, thus eliminating the possibility of amplification of potentially contaminating plasmid DNA.

Effect of gene therapy on urine acidification ability. The shortterm (1 wk) effects of gene therapy on urine $\mathrm{pH}$ are shown in Table I. In normal $\mathrm{C} 3 \mathrm{H}$ strain mice, the baseline urine $\mathrm{pH}$ was $6.3 \pm 0.1$ and after $2 \mathrm{~d}$ of acid loading test the urine $\mathrm{pH}$ dropped to 5.7 \pm 0.1 . CAII-deficient mice had a baseline urine $\mathrm{pH}$ of $7.0 \pm 0.03$ and were unable to acidify urine after acid load. Three groups of CAII-deficient mice received a retrograde injection of DNA/liposome mixture in the renal pelvis. The first and second groups received pCMVCAII in the left kidney and both kidneys, respectively. The third group received pCMV$\beta g a l$ in both kidneys (mock injection). The post-therapy baseline urine $\mathrm{pH}$ was measured $5 \mathrm{~d}$ after treatment and the postacid load urine $\mathrm{pH}$ measured on day 7 when a 2-d course of acid load was completed. Mice that received unilateral injections and mock injections did not have significant changes in baseline urine $\mathrm{pH}$. However, mice that received the bilateral injections had a decreased baseline urine $\mathrm{pH}$ of $6.7 \pm 0.06(P<$

a

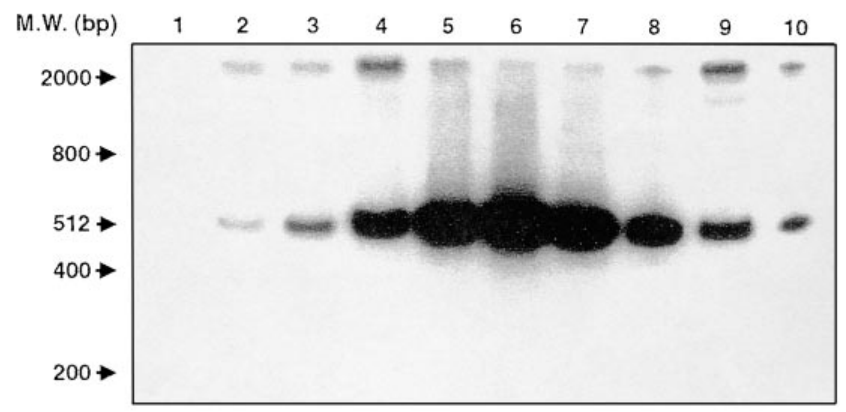

b

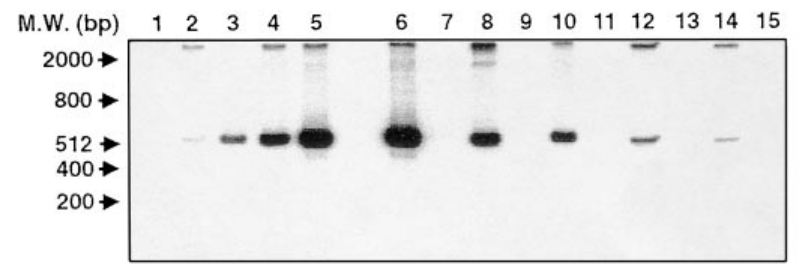

Figure 1. Detection of the human CAII DNA $(a)$ and RNA $(b)$ in CAII-deficient mice kidneys after gene therapy. $a$ shows the detection of the human CAII DNA by PCR. Lanes 1-5 are cDNA standards that represent $0,0.008,0.031,0.125,0.5$ copies of plasmids per genome, respectively (see text). Lanes $6-10$ are kidney DNA from representative animals killed on days $3,7,14,21$, and 32 after gene therapy. $b$ shows the detection of the human CAII mRNA by RTPCR. Lanes $1-5$ are RNA standards that represent a mix of CAII $(+) / C A I I(-)$ total kidney RNA in a ratio $(\mathrm{wt} / \mathrm{wt})$ of $0,1: 1,280,1: 320$, $1: 80$, and 1:20, respectively (see text). Lanes $6,8,10,12$, and 14 are total kidney RNA from representative animals killed on days 3, 7, 14, 21 , and 32 after gene therapy. Lanes 7, 9, 11, 13, and 15 are corresponding samples without RT.
Table I. Urine Acidification After Gene Therapy in CAII-deficient Mice

\begin{tabular}{llc}
\hline \multirow{2}{*}{ Mouse group ( $n)$} & \multicolumn{2}{c}{ Urine $\mathrm{pH}$} \\
\cline { 2 - 3 } & Baseline & Post-acid load \\
\hline $\begin{array}{l}\text { Normal (6) } \\
\text { CAII deficient }\end{array}$ & $6.3 \pm 0.1$ & $5.7 \pm 0.1$ \\
Pre-therapy (18) & & $7.0 \pm 0.03^{*}$ \\
Post-therapy & & \\
$\quad$ Unilateral (4) & $6.9 \pm 0.1$ & $6.4 \pm 0.2^{\ddagger}$ \\
$\quad$ Bilateral (10) & $6.7 \pm 0.06^{\ddagger}$ & $6.2 \pm 0.09^{\ddagger}$ \\
$\quad$ Mock injection (4) & $6.9 \pm 0.1$ & $6.9 \pm 0.1$ \\
\hline
\end{tabular}

Values are mean \pm SE. Post-therapy baseline urine $\mathrm{pH}$ was measured $5 \mathrm{~d}$ after injection and post-acid load urine $\mathrm{pH}$ measured on day 7 when a 2-d course of acid load was completed. $* P<0.05$ vs. normal; ${ }^{\ddagger} P<0.05$ vs. pretherapy or mock injection group.

0.05 vs. pretherapy values). Mice that received unilateral and bilateral injections responded to the acid load by decreasing urine $\mathrm{pH}$ levels to $6.4 \pm 0.2$ and $6.2 \pm 0.09$, respectively (both $P<0.05$ vs. pre-therapy values). In contrast, the animals that received mock injection were unable to acidify urine after acid load. These results indicated that the restored ability to acidify urine in the first and second groups is due to gene therapy with the CAII gene.

Duration of therapeutic effects. Fig. 2 shows the time course of the changes in baseline and post-acid load urine $\mathrm{pH}$ after

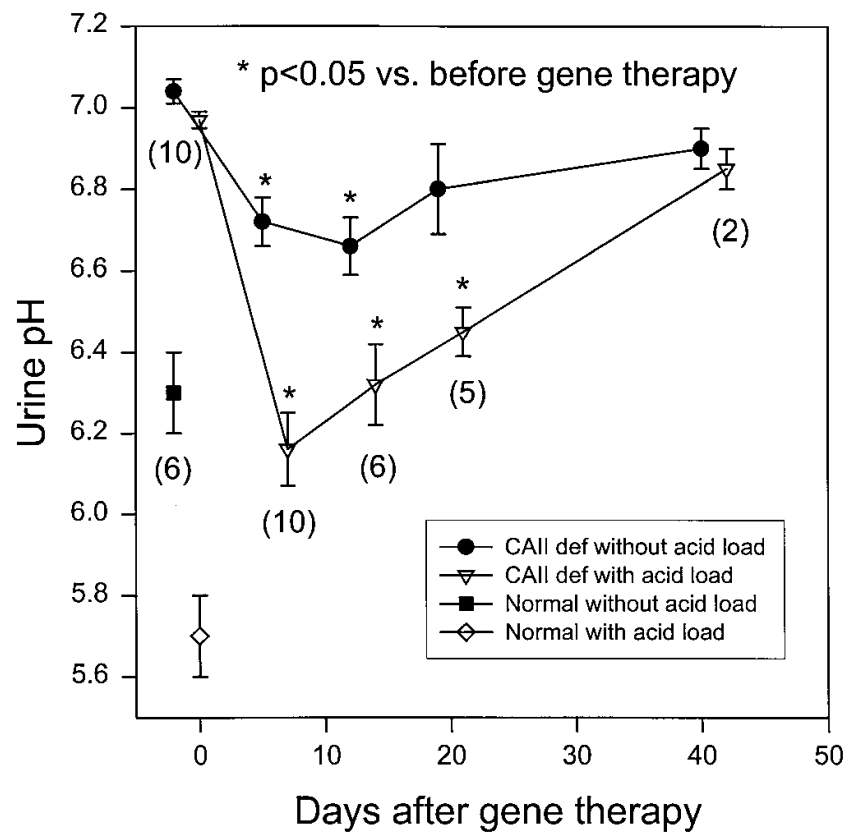

Figure 2. Time course of the changes in pre- and post-acid load urine $\mathrm{pH}$ after gene therapy with bilateral injection. Values are means \pm SE. $n$ is the number of mice of each time point. The pre-and post-acid load urine $\mathrm{pH}$ values of normal mice are also shown. The baseline urine $\mathrm{pH}$ was significantly lower on days 5 and 12; and the post-acid load urine $\mathrm{pH}$ was significantly lower on days 7,14 , and 21 when compared with pre-gene therapy values (all $P<0.05$ ). 
gene therapy with bilateral injection. The baseline urine $\mathrm{pH}$ was $6.7 \pm 0.06,6.7 \pm 0.07,6.8 \pm 0.1$, and $6.9 \pm 0.1$, respectively, on days $5,12,19$, and 40 (days 5 and $12, P<0.05$ vs. pre-therapy values). The post-acid load urine $\mathrm{pH}$ was $6.2 \pm 0.09,6.3 \pm 0.1$, $6.5 \pm 0.06$, and $6.9 \pm 0.1$, respectively, on days $7,14,21$, and 42 (all $P<0.05$ vs. pretherapy values, except day 42 ). Thus, the improvement of urine $\mathrm{pH}$ was observed up to $3 \mathrm{wk}$ after gene therapy.

Tissue distribution of transgene expression. The distribution of the human CAII derived from the transgene in the kidney was investigated using immunohistochemistry studies with antibodies against the human CAII. In the normal kidney, CAII staining was widely distributed, particularly in the inner medullary and cortical regions (Fig. $3 a$ ). The CAII staining was absent in the kidney of CAII-deficient mice (Fig. $3 b$ ). After gene therapy, CAII staining was found mainly in the outer stripe of medulla and corticomedullary junction (Fig. $3 c, 21 \mathrm{~d}$ after gene therapy). No staining of CAII was found in the inner medulla. In a higher power view, only renal tubular cells, but not the vascular or interstitial cells, were positive for CAII (Fig. $3 d$ ). The CAII staining was not detectable in the kidney $42 \mathrm{~d}$ after gene therapy (data not shown).

Blood urea nitrogen level and renal histology. Nephrotoxicity of gene therapy was evaluated with blood urea nitrogen (BUN) and renal histology. BUN levels examined 21 or $42 \mathrm{~d}$ after gene therapy were within normal range $(21 \pm 2 \mathrm{mg} / \mathrm{dl}, n=$ 7, vs. normal level, $22 \pm 1 \mathrm{mg} / \mathrm{dl}, n=10$ ). Renal histology studies revealed no tubular damage or inflammatory reactions associated with gene therapy. The histology of kidney after gene therapy was essentially indistinguishable from that of untreated kidney.

\section{Discussion}

In this report, we demonstrate that liposome-mediated gene therapy on CAII-deficient mice with the human CAII gene substantially corrects renal tubular acidosis for up to $3 \mathrm{wk}$. The time course of changes in the functional study paralleled to the
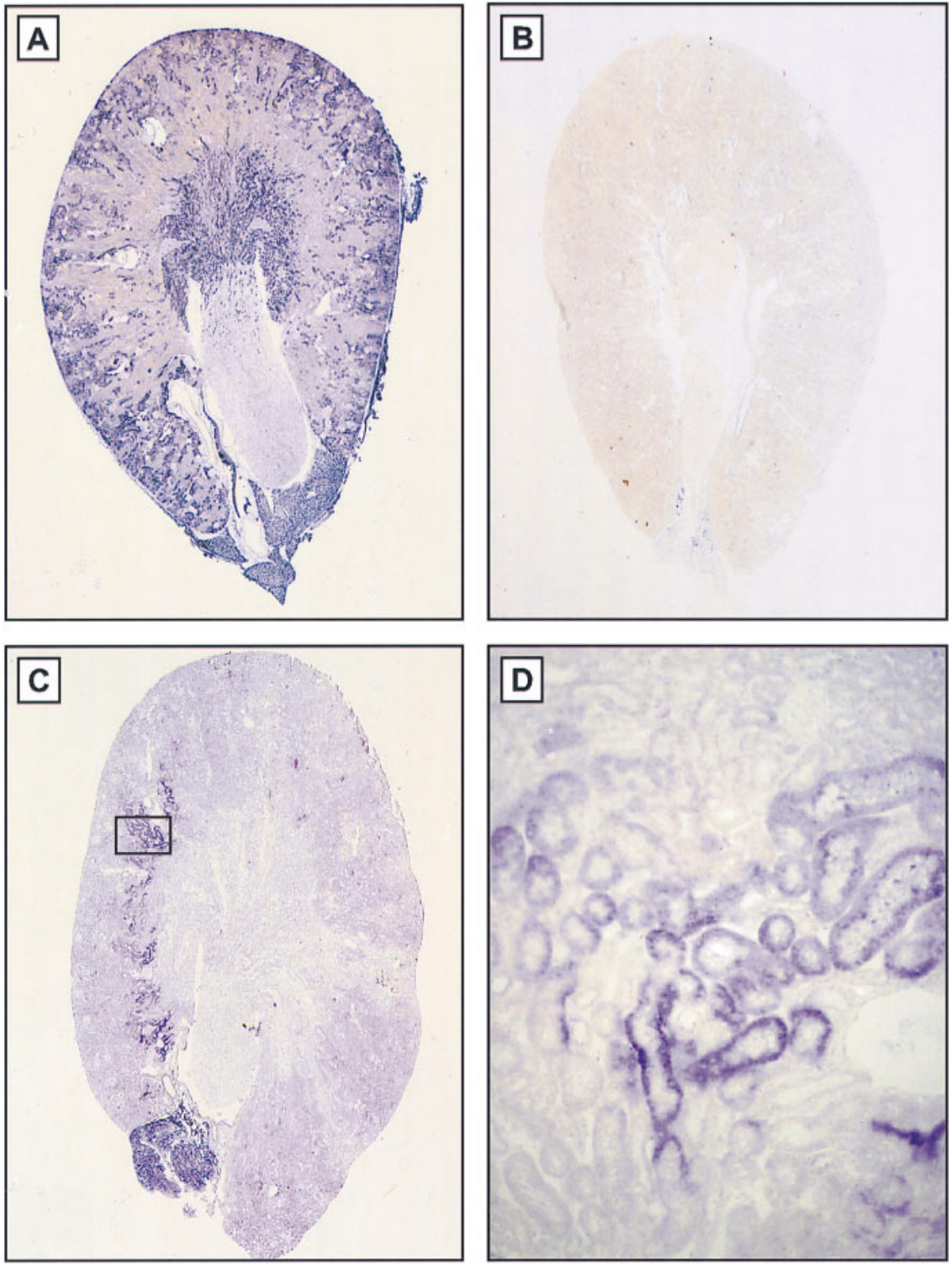

Figure 3. Immunohistochemical staining of kidney sections using anti-human carbonic anhydrase II (CAII) antibodies that recognize both human and mouse CAII. $(A)$ Normal mouse; $(B)$ CAII-deficient mouse; $(C$ and $D)$ representative CAII-deficient mouse 3 wk after gene therapy. $(A-C)$ Low power view; $(D)$ higher magnification of indicated box in Fig. 2 $C$. In normal mice, CAII was found in the proximal tubules, loop of Henle, and collecting ducts (Dark blue). In CAII-deficient mice, there was no staining. After gene therapy, CAII was expressed mainly in the cytoplasm of renal tubular cells in the outer medulla with some staining in the cortex, but not in the inner medulla. 
quantitation of the transgene and its mRNA product. This is the first report showing that liposome-mediated gene therapy can be used for the treatment of renal tubular dysfunctions due to genetic defects.

The observation that urine $\mathrm{pH}$ decreased only after transfection with the human CAII gene but not with the mock gene, pCMV $\beta$ gal, indicating that restoration of CAII gene leads to the correction of renal tubular acidosis. The ability to acidify urine was substantially but not completely restored after gene therapy. The effect of transgene appears to be dose dependent because urine $\mathrm{pH}$ decreased more in mice that received bilateral injection than those with unilateral injection.

The transient effect of liposome-mediated gene therapy is expected because the transgene is not incorporated into the chromosome (19). The expression of the transgene lasted for about three weeks, a finding consistent with our previous study using $\beta$-galactosidase cDNA with the same delivery system (8). It is possible that this limitation is due to degradation of the delivered DNA over time (19). Recently, Thierry et al. (20) have shown that the duration of luciferase gene expression after intravenous liposome-based delivery of a CMVdriven expression plasmid was increased from several weeks to several months by the inclusion of human papovavirus DNA sequences necessary for the episomal replication of the expressed plasmid in mouse cells. This strategy may possibly be applied to increase the retention of DNA and the duration of gene expression in the kidney. Alternatively, since DNA-liposome complexes are not immunogenic, repeated administration of these complexes over time into the renal pelvis could maintain longer term expression of the delivered gene. Recently, Song et al. (21) reported that repeated intravenous injection of luciferase-liposome complex in mice could maintain the same levels of transgene expression as the first injection. Similarly, Goddard et al. (22) reported that a second dose of a cystic fibrosis transmembrane conductance regulator (CFTR) cDNA-liposome complex is as effective as the first dose in restoring cAMP-dependent chloride secretion to null $\mathrm{CF}$ mice trachea. This double treatment was well tolerated with no discernible inflammation of lung tissues (22). The safety issue of intrarenal-pelvic delivery of gene therapy has been addressed previously (8) and in this study. The BUN levels in mice received intrarenal-pelvic injection of either pCMVßgal (8) or pCMVCAII in combination with Lipofectin were within the normal range. There were no apparent histological abnormalities in the injected kidney. These results suggest that a successful gene transfer with DNA-Lipofectin is not associated with any significant renal damage.

Our methodology of gene therapy in mice can be easily adopted to humans. Therapeutic genes can be delivered to the renal pelvis with a flexible ureterorenoscopy. The tissue distribution of gene expression after intrarenal-pelvic gene therapy is quite unique: the transgene was only expressed in the outer medulla and corticomedullary junction. These results are similar to our previous studies using the $\beta$-galactosidase plasmid (8). It is not clear why there is no transgene expression in the inner medulla. We speculate that the high salt and urea content in the inner medulla may affect the entry of DNA-liposome complex. Since this retrograde approach mainly transfects the outer medulla, the genetic defects affecting these regions may benefit from this type of treatment. Diseases with such characteristics include congenital nephrogenic diabetes insipidus, Bartter's syndrome, Gitelman's syndrome, medul- lary cystic disease, familial juvenile nephronophthisis, and others. The genetic defects in the first three syndromes have been well characterized: congenital nephrogenic diabetes insipidus is caused by a defective vasopressin (V2) receptor (23) or water channel (24), Bartter's syndrome by a defective potassium channel (25) or the furosemide-sensitive $\mathrm{Na} / \mathrm{K} / 2 \mathrm{Cl}$ cotransporter (26), and Gitelman's syndrome by a defective thiazidesensitive $\mathrm{Na} / \mathrm{Cl}$ cotransporter (27). Our experimental model serves as a prototype of gene therapy targeting to renal tubular cells. It will be useful for testing various strategies to improve transfection efficiency and duration of gene expression. Once refined, this gene delivery system can be applied to patients with a variety of renal tubular dysfunction due to genetic defects.

\section{Acknowledgments}

We thank Drs. Patrick Venta and Richard Tashian for providing the CAII cDNA and Mr. Landon Inge for immunochemistry studies.

This work was supported by the Arizona Elk's Foundation Transplant Research Grant and the Southern Arizona Foundation grant to L. Lai, and National Institutes of Health grant RO1DK52358 and a grant from the Dialysis Clinic, Inc., a nonprofit organization, to Y.H. Lien.

\section{References}

1. Tashian, R.E. 1992. Genetics of the mammalian carbonic anhydrases. Adv. Genet. 30:321-355.

2. Lonnerholm, G., and Y. Ridderstrale. 1980. Intracellular distribution of carbonic anhydrase in the rat kidney. Kidney Int. 17:162-174.

3. Tashian, R.E. 1989. The carbonic anhydrases: widening perspectives on their evolution, expression and function. BioEssay. 10:186-192.

4. Sly, W.S., D. Hewett-Emmett, M.P. Whyte, Y.-S.L. Yu, and R.E. Tashian. 1983. Carbonic anhydrase II deficiency identified as the primary defect in the autosomal recessive syndrome of osteopetrosis with renal tubular acidosis and cerebral calcification. Proc. Natl. Acad. Sci. USA. 80:2752-2756.

5. Lewis, S.E., R.P. Erickson, L.B. Barnett, P.J. Venta, and R.E. Tashian. 1988. $N$-ethyl- $N$-nitrosourea-induced null mutation at the mouse Car2 locus: an animal model for human carbonic anhydrase II deficiency syndrome. Proc. Natl. Acad. Sci. USA. 85:1962-1966.

6. Brechue, W.F., E. Kinne-Saffran, R.K.H. Kinne, and T.H. Maren. 1991. Localization and activity of renal carbonic anhydrase (CA) in CAII deficient mice. Biochim. Biophys. Acta. 1066:201-207.

7. Curtis, P.J. 1983. Cloning of mouse carbonic anhydrase mRNA and its induction in mouse erythroleukemic cells. J. Biol. Chem. 258:4459-4463.

8. Lai, L., G.W. Moeckel, and Y.H. Lien. 1997. Kidney-targeted liposomemediated gene transfer in mice. Gene Ther. 4:426-431.

9. Lien, Y.H., and L. Lai. 1997. Liposome-mediated gene transfer into the tubules. Exp. Nephrol. 5:132-136.

10. Lien, Y.H., and L. Lai. 1997. Gene therapy for renal diseases. Kidney Int. 52(Suppl. 61):S85-S88.

11. Felgner, P.L, T.R. Gadek, M. Holm, R. Roman, H.W. Chan, M. Wenz, J.P. Northrop, G.M. Ringold, and M. Danielsen. 1987. Lipofection: a highly efficient, lipid-mediated DNA-transfection procedure. Proc. Natl. Acad. Sci. USA. 84:7413-7417.

12. Zhu, N., D. Liggitt, Y. Liu, and R. Debs. 1993. Systemic gene expression after intravenous DNA delivery into adult mice. Science. 261:209-211.

13. Stewart, M.J, G.E. Plautz, L.D. Buono, Z.Y. Yang, L. Xu, X. Gao, L. Huang, E.G. Nabel, and G.L. Nabel. 1992. Gene transfer in vivo with DNAliposome complexes: safety and acute toxicity in mice. Hum. Gene Ther. 3:267275 .

14. Nabel, G.L, E.G. Nabel, Z. Yang, B.A. Fox, G.E. Plautz, X. Gao, S. Shu, D. Gordon, and A.E. Chang. 1993. Direct gene transfer with DNA-liposome complexes in melanoma: expression, biologic activity, and lack of toxicity in humans. Proc. Natl. Acad. Sci. USA. 90:11307-11311.

15. Caplen, N.J., E. Alton, P.G. Middleton, I.R. Dorin, B.J. Stevenson, X. Gao, S.R. Durham, P.K. Jeffery, M.E. Hodson, C. Coutelle, et al. 1995. Liposome-mediated CFTR gene transfer to the nasal epithelium of patients with cystic fibrosis. Nat. Med. 1:39-46.

16. Alino, S.F., M. Bobadilla, J. Crespo, and M. Lejarreta. 1996. Human alpha lantitrypsin gene transfer to in vivo mouse hepatocytes. Hum. Gene Ther. 7:531-536.

17. Wheeler, C.J., P.L. Felgner, Y.J. Tsai, J. Marshall, L. Sukhu, G. Doh, J. 
Hartikka, J. Nietupski, M. Manthorpe, M. Nichols, et al. 1996. A novel cationic lipid greatly enhances plasmid DNA delivery and expression in mouse lung. Proc. Natl. Acad. Sci. USA. 26:11454-11458.

18. Bernt, E., and H.U. Bergmeyer. 1965. Urea. In Methods of Enzymatic Analysis. H.U. Bergmeyer, editor. Academic Press, New York. 401-406.

19. Ledley, F.D. 1995. Nonviral gene therapy: the promise of genes as pharmaceutical products. Hum. Gene Ther. 6:1129-1144.

20. Thierry, A.R., Y. Lunardi-Iskandar, J.L. Bryant, P. Rabinovich, R.C. Gallo, and L.D. Mahan. 1995. Systemic gene therapy: biodistribution and longterm expression of a transgene in mice. Proc. Natl. Acad. Sci. USA. 92:97429746.

21. Song, Y.K., F. Liu, S. Chu, and D. Liu. 1997. Characterization of cationic liposome-mediated gene transfer in vivo by intravenous administration. Hum. Gene Ther. 8:1585-1594.

22. Goddard, C.A., R. Ratcliff, J.R. Anderson, E. Glenn, S. Brown, D.R. Gill, S.C. Hyde, L.J. MacVinish, L. Huang, C.F. Higgins, et al. 1997. A second dose of a CFTR cDNA-liposome complex is as effective as the first dose in restoring cAMP-dependent chloride secretion to null $\mathrm{CF}$ mice trachea. Gene Ther. 4:1231-1236.

23. Rosenthal, W., A. Seibold, A. Antaramian, M. Lonergan, M.F. Arthus,
G.N. Hendy, M. Birnbaumer, and D.G. Bichet. 1992. Molecular identification of the gene responsible for congenital nephrogenic diabetes insipidus. Nature. 359:233-235.

24. van Lieburg, A.F. M.A. Verdijk, V.V. Knoers, A.J. van Essen, W. Proesmans, R. Mallmann, L.A. Monnens, and B.A. van Oost. 1994. Patients with autosomal nephrogenic diabetes insipidus homozygous for mutations in the aquaporin 2 water-channel gene. Am. J. Hum. Gene. 55:648-652.

25. Simon, D.B., F.E. Karet, J. Rodriguez-Soriano, J.H. Hamdan, A. DiPietro, H. Trachtman, S.A. Sanjad, and R.P. Lifton. 1996. Genetic heterogeneity of Bartter's syndrome revealed by mutations in the K+ channel, ROMK. Nat. Genet. 14:152-156.

26. Simon, D.B., F.E. Karet, J.M. Hamdan, A. DiPietro, S.A. Sanjad, and R.P. Lifton. Bartter's syndrome, hypokalaemic alkalosis with hypercalciuria, is caused by mutations in the Na-K-2Cl cotransporter NKCC2. Nat. Gene. 13: 183-188.

27. Simon, D.B., C. Nelson-Williams, M.J. Bia, D. Ellison, F.E. Karet, A.M. Molina, I. Vaara, F. Iwata, H.M. Cushner, M. Koolen, et al. 1996. Gitelman's variant of Bartter's syndrome, inherited hypokalaemic alkalosis, is caused by mutations in the thiazide-sensitive Na-Cl cotransporter. Nat. Genet. 12:24-30. 